\title{
Overcoming the "Other's" Stigma: Arab and Muslim Representations in US Media and Academia
}

\author{
Lanouar Ben Hafsa ${ }^{1}$ \\ ${ }^{1}$ University of Tunis, Faculty of Human and Social Sciences, Tunisia \\ Correspondence: Lanouar Ben Hafsa, University of Tunis, Faculty of Human and Social Sciences, Tunisia.
}

Received: June 19, 2019

Accepted: July 17, $2019 \quad$ Available online: August 13, 2019

doi:10.11114/ijsss.v7i5.4446

URL: https://doi.org/10.11114/ijsss.v7i5.4446

\begin{abstract}
The present work focuses on Arab and Muslim representations in U.S. media and academia. It suggests to offer an overview of the collective and often stereotyped image of such categories amidst shifting ideological and political contexts. While it rests upon deep investigation of the literature underlying Orientalist discourse, it by no means aims to delve into the controversy purporting to the core tenets of such an age-old trend tackled extensively by renowned scholars like Edward Said and Jack Shaheen. Rather, it endeavors to contribute novel insights into the way Arabs and Muslims are depicted and perceived in the United states, by deconstructing certain Orientalist binary frames to demonstrate, ultimately, how both spheres of influence (media and academia) mimic the same political language and work in conjunction to propagate a Eurocentric culture. The study, eventually, adopts a quantitative approach based on the analysis of literature contents using statistical data to justify and substantiate discussed arguments. It, regrettably, does not cover all American media outlets due to the immensely broad scope of the addressed matter.
\end{abstract}

Keywords: Arab Americans, American Muslims, misrepresentation, media, academia

\section{Introduction}

This study endeavors to address the controversial issue of Arab and Muslim representations in American media and academia. While it states that the widely conveyed negative image of such groups is not a new phenomenon and stresses its multifaceted character, it attempts to demonstrate that it is basically political and has recurrently been utilized to support a political agenda. Actually, dealing with such a complex subject poses more than a problem, as we need first to frame the anti-Arab and anti-Muslim discourse within clear-cut boundaries, especially tackle their misrepresentations under its diverse shapes and configurations.

However, investigating bias against Arabs and Muslims (often believed to be mutually exclusive) implies tracking it in both mainstream media and academia. As of the first and due to its broad scope, research will concentrate only on certain print and broadcast outlets that widely showcase such a phenomenon. But anti-Arab and anti-Muslim stance is also a distinctive feature of Orientalist discourse propagated by influential scholars like Samuel Huntington, Bernard Lewis, and today Daniel Pipes. Overall, while it embraces a quantitative method based on content analysis and evidenced by gathered empirical data, it tries to provide counter-arguments to widely held assumptions regarding Arabs and Muslims. Due, finally, to the extreme scarcity of published material dedicated to that purpose, one would expect inconclusive results to be reached through this work.

The study at hand revolves around three broad questions:

First, it demonstrates that the 'Othering' process of 'us' vs. 'them' paradigm as reflected in the discourse of certain U.S. media and within certain academic circles is not a new phenomenon. Even though the misrepresentation of Arabs and Muslims increased tremendously in the post-9/11 era, in conjunction with the development of sophisticated means of communication, it has been constructed over time, dating back to the Crusades of the $12^{\text {th }}$ century. While it traces the history and evolution of Orientalist thought based on literature dedicated to that purpose, it tries to capture the essence of such trend, namely grapple with its different facets and manifestations.

Second, it provides further insights into the dynamics underscoring the 'Othering' process. To this end, it highlights the crucial role jointly played by newsmakers and critics in the academia (even if the bridge between the two realms is not direct and remains to clarify) in propagandizing for the Orientalist discourse, and explores the rhetoric strategically 
framed in both domains to disseminate anti-Arab and anti-Muslim literature and construct otherness based especially on religious affiliation.

Finally, it explores the rhetorical and strategic mechanisms used by American news agents and right-wing polemicists to sketch the image of the Arab and Muslim as the enemy. Likewise, based on empirical media studies, it attempts to 'decontextualize' and deconstruct binaries fostering the production of Orientalism such as 'Orient vs. Occident', 'civilization vs. barbarism', chiefly the 'us vs. them' dichotomy. More importantly, it strives to highlight the complementary role played by both actors to perpetuate Arab and Muslim misrepresentation, and demonstrate ultimately that news coverage and Orientalist discourse mimic policy language.

\section{Orientalism: Meaning and Historical Background}

A close look at the multifaceted character of Orientalism reveals deep-seated complexities in trying to define and interpret it. Even though considered as one of its uncontested experts, Edward Said in his well-known book Orientalism (1987) does not provide a universally applicable definition of this concept (Schmidt, 2014: 138). Rather, he juxtaposes three overlapping perceptions of the construct where he first defines the Orientalist as "anyone who teaches, writes about, or researches the Orient" (Said, 1987: 2); second, Orientalism as "a style of thought based upon an ontological and epistemological distinction made between 'the Orient' and (most of the time) 'the Occident"' (Said: 1987: 2); and third the credo as a "corporate institution for dealing with the Orient - dealing with it by making statements about it, by teaching it, settling it, and ruling over it: in short, Orientalism as a Western style for dominating, restructuring and having authority over the Orient" (Said, 1987: 3).

In line with Said's perspective, it is worthwhile to notice that, based on the dichotomy of 'West' vs. 'East', Orientalism is not a new phenomenon. Nor is it the produce of global historical events only. Constructed over centuries and reinforced with sustained effort to maintain Western hegemony that, in terms of Said, "gives Orientalism (...) duality and strength" (Said, 1987: 7), animosity between Christian 'Occident' and Islamic 'Orient' had been palpable as early the $12^{\text {th }}$ century. For instance, stories disseminated about Prophet Muhammad portrayed him as a heathen "idol who (was) worshipped like a Greek god" (Ernst, 2003: 16).

Attempts to perpetuate the Western moral and cultural supremacy persevered through the late Middle Ages with an unrevealed intent to advance the Crusades and conquer Muslim territories, ruled at the time by Arabs and Turks (Ernst, 2003: 16). The same anti-Muslim narrative persisted through the Renaissance and Enlightenment eras. To take just one example, French thinker Voltaire who espoused an 'anti-Orient' stance wrote, "Islam is about Muhammad who rose to heaven and having received there part of his unintelligible book which affronts common sense in every page" (Richardson, 2004: XIX-10-17).

Interestingly, tracing the trajectories of Orientalist discourse in U.S. media started as early as the 1920s, with the advent of silent movies. Concomitant with a sustained ethno-centric sentiment stressing Western superiority, it in fact stemmed from a series of negative attitudes and judgments widely conveyed in $19^{\text {th }}$ century travel accounts and stereotypically reproduced in Hollywood epics. In this respect, Jack Shaheen, probably the best-known scholar addressing Arab and Muslim negative portrayal in American entertainment industry, presented an insightful analysis of Arab and Muslim depiction in U.S. movies and T.V. programs. In his famous documentary book Reel Bad Arabs: How Hollywood Vilifies a People (2001), Shaheen examined stereotypes and biases used in association with Arabs and Muslims in American motion pictures. After scrutinizing more than 900 movies released between 1896 and 2001, he concluded that almost all Hollywood depictions of these groups were demeaning and disrespectful of their culture and history. As a case in point, while Arab and Muslim men were often called by slurs such as 'assholes,' 'bastards,' 'camel dicks, 'pigs', 'jackals,' 'rats,' 'rag-heads,' 'scum-buckets,' 'buzzards of the jungle,' and 'sons of whores,' their female counterparts were featured as 'bosomy belly dancers' or 'mute and submissive,' and 'Arab children are never seen unless they are out to steal your wallet' (Shaheen, 2000: 22-24).

What's more, by presenting Arabs and Muslims as a pestilential threat and the Middle East as standing for an exotic but threatening culture, Hollywood filmmakers, according to Shaheen, did not only project the bulk of these communities as 'villains,' 'cowardly,' and 'barbaric', but also helped engrave a malignant stereotype in popular minds that further alienated them as the different 'Other'. Thus, in creating a certain lens through which the Orient was viewed at the same time as a world of fantasy and a perilous place, Hollywood movies reinforced, in his view, the concept of 'otherness' by segregating Arabs and Muslims as primitive, backward and violent people (McAlister, 2005: 8-9).

Misrepresentation of Arabs and Muslims in American media did not stop at Hollywood motion pictures only. It gained momentum with the advent of television in the 1950s, and recently the development of new technologies and sophisticated means of mass communication. In his book The TV Arab (1984), for instance, Shaheen illustrated how the U.S. entertainment industries fabricated a prejudiced picture of such groups, featuring them as "buddies, billionaires, bombers, and belly dancers" (Shaheen, 1984: 4). After reviewing about 300 television programs aired during the 
1975-1976 and 1983-1985 TV seasons (ranging from cartoons to comedy shows and police series), he concluded that a striking majority among them did not project a truthful image of the above-mentioned communities. Rather, they propagated "four basic myths about Arabs: they are all fabulously wealthy; they are barbaric and uncultured; they are sex maniacs with a penchant for white slavery; they reveal in acts of terrorism" (Shaheen, 1984: 4).

The emergence of terrorism as a dominant media frame after the $9 / 11$ attacks added a new layer to the constructed representation of Arabs and Muslims in U.S. media, and gave way to a renewed version of Orientalism that further accentuated the dichotomization process. Actually, even though omnipresent across in the aforementioned realm, long before September 11, the stereotype of Arabs and Muslims as 'warmongers' with a 'natural' propensity for violence came to complement the one scapegoating them as dominating the world's wealth, and holding them responsible for rising oil prices and the ensuing global economic and financial recessions. As clearly pointed out by Said in his book Covering Islam (1981): "it is only a slight overstatement to say that Muslims and Arabs are essentially covered, discussed, apprehended, either as oil suppliers or as potential terrorists" (Said, 1981: 26).

By and large, Hollywood's alienating picture of the Arab and Muslim 'Other', according to Shaheen, was not only meant to entertain an American audience with often vague and rudimentary knowledge of their cultural heritage. Arab and Muslim stereotypes, he argued, were also politically-motivated, even if there was no explicit evidence proving that Hollywood was following a particular political agenda (Shaheen, 2000: 23).

\section{The Arab and Muslim 'Other'}

\subsection{From Exoticism to Realism}

By no means an overused cliché after roughly a century of Arab and Muslim denigration, Orientalism has remained highly vivid in present-day discourses, coinciding with the advent of information technologies and changing geopolitical contexts. In effect, more than a set of stereotyped binaries, the widely discussed construct has emerged in recent times as a dexterous tool of political instrumentalization. As such, it becomes relevant to frame the debate over Arab and Muslim misrepresentation within shifting historical and ideological paradigms, and highlight opinion leaders' role, both in the media and academia, not only in reinvigorating the 'Othering' process of 'us' vs. 'them,' but also in shaping popular perception of those categories.

Arguably, images of 'reel bad Arabs and Muslims' that pervaded Hollywood motion pictures since the early days of silent movies could not be ascribed to the single attribute of propagating an exotic vision of those categories. More often than not, they were determined by a sustained need to reaffirm Western cultural and moral hegemony, especially maintain political control over what Orientalists labelled 'oppressive' and 'dictatorial' Middle Eastern regimes. In addition to standing for an overarching ideology rooted in a binary thought stigma, Orientalism has often been perceived as a state of mind constructed, over time, around a number of frames including race, religion and gender. More importantly, it has often been driven by political and economic interests, and sustained by large-scale historical events that intermittently brought to surface underpinning clashes between 'Orient' and 'Occident'. In this respect, World War II could be considered as a turning point that propelled the United States as a major political and economic actor on the international scene.

Concomitant with the new role of the U.S. as a global power, commitment to support the newly founded state of Israel in 1948 could be read in this regard as both part of its containment strategy, and a momentous linchpin of its new foreign policy. In her book Epic Encounters (2005), American Studies specialist Melani McAlister pointed out what she called "the often invisible significance of the Middle East to American foreign policy" (McAlister, 2005: 35). While she stressed the Biblical roots associated with the Middle East, she revealed the political and economic interests underlying American involvement in that region, especially its unequivocal support for the state of Israel.

In the same context, Lina Khatib in her book Filming the Middle East (2006) highlighted how Hollywood misrepresentation of Arabs and Muslims as 'inferior' and 'backward' people persevered in the postwar era, and how the concept of 'otherness' has even been amplified to serve U.S. foreign policy objectives in the Middle East (Khatib, 2006).

The same stance was shared by other scholars, namely Michael Suleiman, who believed that Hollywood representation of the Middle East "ebbed and flowed with the foreign policy relations of the United States across time" (qtd. in Fries, 2005: 320). Suleiman asserted that the U.S. movie industry had often been used as a propaganda tool to perpetuate negative stereotypes against Arabs and Muslims to finally justify American interference in that area of the world (Suleiman, 1999: 34). To take just one example, the Hollywood epic Exodus (1960) which depicted the Jewish people ordeal in Nazi Germany and their quest to reach Palestine, bore, according to Shaheen, an outspoken message of sympathy toward the state of Israel, confirming, in his view, the "American impressions of Israelis as heroes, and of Arabs as villains" (Arti, 2007: 8). 
The 1967 Arab-Israeli War, as a key event in U.S. involvement in the Middle East, underscored the persistence of the Orientalist rhetoric, and further confirmed American media bias in favor of the Hebrew state. In his book (Re-) Framing the Arab / Muslim (2014), Silke Schmidt explored how mainstream media framing of the Six-Day War (1967) profoundly altered the American public view of the Middle East in general, and the Israeli-Palestinian conflict in particular (Schmidt, 2014: 52-53). In the same stream of thought, Louise Cainkar explicated how U.S. news outlets (print and broadcast) portrayed Arabs and Muslims as 'aggressors' and racialized them as 'inferior' (Cainker, 2009). But to Said who depicted the Orient and Occident cultural war as a struggle between David and Goliath, the 1967 conflict marked the beginning of a "long conflict-laden political history" (Schmidt, 2014: 155).

However, U.S. media (including the movie industry) did not maneuver their outputs so as to be in line with foreign policy orientations only. They often took center stage when the American economic interests were at stake. As a matter of fact, when in 1973 Saudi Arabia imposeed an embargo on oil exports to the United States as a retaliatory measure against its support of Israel in the Yom Kippur War, mainstream American media reacted by scapegoating Arabs and Muslims as a growing threat to U.S. economic stability (Khatib, 2006: 10). As a result, the image of the Arab/Muslim as a 'rapist,' driven by his sexual desire, shifted to the 'rich,' 'greedy' and 'extravagant' 'oil sheik' stereotype to whom we imputed skyrocketing oil prices and ensuing financial recessions. Hence, a widespread call to reduce oil consumption and economic dependence on the Middle East, as echoed in the widely circulating slogans 'The Faster You Drive, The Richer They Become,' or 'Driving 75 Is Sheik, Driving 55 Is Chic' (Shaheen, 1984: 15).

The Orientalist discourse resurfaced a few years later, subsequent to the 1979 Iranian Hostages Crisis, to give way to a repertoire of binary vocabulary meant to activate and sustain a stereotypical schemata based on 'us' vs. 'them' or 'barbarism' vs. 'civilization' dichotomies (Wöhlert, 2007: 31). For instance, opinion polls conducted in 1981 highlighted the key role mainstream media played in reframing American public perception of Arabs and Muslims (even if Iranians were not Arabs), as demonstrated in their excessive use of adjectives such as 'barbaric,' 'cruel,' 'treacherous,' and 'bloodthirsty' in reference to them (Cainker, 2004: 88).

Featuring Arabs and Muslims as 'Bedouins' incessantly 'enjoying harem ecstasies' or 'galloping with their swords through the desert' amounts to scratching the surface when one explores the rhetoric publicized by Orientalism propagandists on the eve of the First Gulf War (1990-91), codenamed 'Operation Desert Shield.' More importantly, it coincided with the collapse of the former Soviet Union in 1991, signaling the end of the Cold War. Even though limited in scope, as the size of its audience remained minimal compared with that of media outlets, Orientalist discourse played a key role in shaping American people's and leaders' view of Islam, especially how they made sense of the Middle East.

Symptomatic of the new move to perpetuate the Orientalist legacy was the overarching narrative associated with Islam. In actuality, the demise of Communism as a core entity and an ideological system of government enticed the West (namely the United States) to generate a new enemy frontier which they had to defeat in order to reclaim their superiority. Seen from such a perspective, the religion of Islam came on this account to be depicted, not only as a new threat to Western democracies, but also as a 'green menace' supplementing the 'red scare.'

The idea of presenting Islam as a dangerous faith rooted in violence and irrationality got into the academic writings of two well-known scholars, Samuel P. Huntington and Bernard Lewis, who seized the new global conjuncture to disseminate a 'culture of fear' of such a faith, and reinforce the 'us' vs. 'them' paradigm (Conte, 2001: 1031). Based on the dialectic that the 'civilized' required the 'barbaric' to survive, Islam came then to be represented as 'medievally' backward, static, and incapable of change and renewal (Poole, 2002).

Assaults on Islam and attempts to reinvent the Cold War, with Muslims featured as the new enemies to the West, opened up a new chapter in the debate over Orientalist rhetoric, and inaugurated a new cycle in the 'Othering' process. In his book The Clash of Civilizations and the Remaking of World Order (1996), Huntington pointed out in this context that opposition between Islam and the West was inherently embedded in the violent nature of such a religion, and could by no means be attributed to certain historical or political circumstances. In the same vein, Lewis in his article "The Roots of Muslim Rage" (The Atlantic, Sept. 1990) highlighted the fracture between 'Orient' and 'Occident', and even questioned the likelihood of peaceful coexistence between 'Islam' and the 'West'. He stressed: "It should by now be clear that we are facing a mood and a movement far transcending the level of issues and policies and the governments that pursue them. This is no less than a clash of civilizations - the perhaps irrational but surely historic reaction of an ancient rival against our Judeo-Christian heritage, our secular present, and the worldwide expansion of both" (Lewis, 1990: 60).

\subsection{9/11 as a Turning-point in the Debate over Orientalism}

The 9/11 attacks on the World Trade Center and the Pentagon in 2001, and the ensuing 'War on Terror' declared by President Bush to eradicate terrorists from the surface of the earth (Bush, 2001) marked a deep watershed in the history of Orientalist thought. They not only gave rise to new frame patterns stigmatizing Arabs and Muslims as the 'Other,' but 
also designated them as the enemies of the West. Now based on the belief that the attacks were perpetrated by Muslim activists, terrorism became systematically associated with Islam as the antithesis of Western democracy. For both news agents and Orientalist scholars, a new type of terrorism meant a new Muslim discourse to magnify the Islamic threat and gather public support for the government's anti-terrorist measures. From then on, perpetuating Orientalist rhetoric became a common cause to both media and academia which, in the name of national security, contributed a great deal to the war on terror effort and even became the government's mouthpiece in this regard.

Based on the logic of 'Othering,' namely to promote a rigid conception of the Arab/Muslim enemy, opinion leaders in both spheres of influence not only questioned the core tenets of Islam as a religion that, according to them, preached hatred and violence against non-Muslims, but especially pinpointed the homogenizing nature of such a faith. As such, the 9/11 attacks, in their view, could by no means be ascribed to a tiny fringe of radical obscurantists, but to all Muslims, regardless of their national origin, ethnicity, or their degree of adherence to political Islam and the restoration of the Caliphate (Reza, 2011).

In such a line of thought, the subsequent framing of Muslims as global prototypes came to transcend cultural and geographic boundaries, and paint a stereotypical portrait of Muslims as born-to-kill terrorists constructed in the same mold. Bearing this in mind, there was no need for neo-Orientalists (post-9/11 Orientalists) to distinguish between Muslims in the Middle East and their coreligionists in the diaspora, since all of them were potential terrorists. As of those among them who chose to live in the West, mainly in the United States, they merely represented the 'threat within,' a kind of ' 5 th column' or dormant cells conspiring to perpetrate attacks with the ultimate goal to 'Islamize' America (Pipes, 2003). With respect to Arab Americans, often associated with Islam, a hybrid identity (Arab and American) simply became unattainable. Worse, President Bush's division of the world into terrorists and anti-terrorists, as embodied in his popular slogan "you're either with us or with the terrorists" (Schmidt, 2014), further marginalized them as images of 'external Arabs' and 'internal Arabs and Muslims' became tightly interwoven in the mind of many Americans (Wöhlert, 2004: 18). As expressly pointed out by Schmidt, "This trajectory has especially fostered the conflation of the internal with the external Arab in the eye of the American public. Even more, the Arab is not merely 'Arab'or 'Muslim' anymore, he/she has become the incarnation of a stereotypical terrorist" (Schmidt, 2014: 162).

Rising voices against Islam in the academia often found their echo in media outlets where the clash of civilizations paradigm was frequently highlighted and even showcased after $9 / 11$ events. In addition to Muslims' alleged 'untrustworthiness,' chiefly their 'inability' to cohabit peacefully with non-Muslims, their negative depiction across the American news outlets and entertainment industry further fostered Orientalist discourse with the purpose to demonize them in public opinion and fuel hatred and discrimination against them (Reza, 2011: 236).

Furthermore, sustained by the new context of war on terror, the post-9/11 framing of Arabs and Muslims continued to draw on Orientalist ideology, this time presenting "all Muslims and all Arabs as terrorists" (Schmidt, 2014: 163). Accordingly, anti-Arab/Muslim rhetoric came to the fore to paint an alarming picture of the terrorist threat and amplify public fear. More concerned about the perilous ramifications of political Islam, the Arab/Muslim was sketched as the sworn public enemy for everything the West stood for. Simultaneously, an overview of empirical studies conducted on the eve of the Second Gulf War (2003) confirmed the persistence of previous frame patterns, but also revealed the dominance of new stereotypes targeting Arabs and Muslims as 'bearded, bloodthirsty terrorists' (Cainker,2004: 85).

Further, the war on Iraq as part of the war on terror restructured old framing processes, namely the dominance of binary language pitting 'West' against 'East.' Hence, the use in the media of terms such as 'peace,' 'security,' and 'progress,' in contrast to 'war,' terrorism,' and 'barbarism.' (Schmidt, 2104). As specified by Sandrikcioglu: 'this culture-specific cognitive model helped frame the debate about the Gulf crisis by conceptualizing Iraq as the incarnation of the Orient [...] which has been symptomatic of the age-old relationship between the Orient and the West" (Sandrikcioglu, 2010:153).

In a similar vein, Debra Merskini provided an in-depth analysis of the strong impact media framing had on public discourse in connection with the war on terror. She specifically highlighted the degree of influence media, as a 'fourth state,' harbored in American society, chiefly its ability to transform the strife into an open 'us' vs. 'them' clash. She held: "the 'Face of Terror' is not only that of Osama bin Laden and Saddam Hussein but all persons of Arab descent, evoking the simulacrum of all Middle Easter-looking men as the face of terrorism" (Merskini, 2004: 163).

Meanwhile, the upswing of terrorism as a dominant media frame in the post-9/11 era continued to discredit Arab Americans' sense of national belonging and their status as full American citizens. It, according to Mervat Hatem, "pitted their Arab and American identities against one another" (Hatem, 1998: 376). Worse, stereotyped in certain media outlets as potential activists waiting for orders from international terrorist networks or rogue states, their loyalty to the American nation was severely questioned and their dual identity became increasingly unattainable. As metaphorically summarized by a radio commentator at the time: "In war there are no hyphenated Americans, just Americans and 
non-Americans" (qtd. in Hatem, 1998: 373).

In the same context, research conducted on CNN coverage of the war on terror in the post-9/11 period revealed the same trend, namely the use of affective bias to evoke fear in the audience and legitimize political measures taken to contain the terrorist menace. It clearly laid bare an overwhelming drive to encourage and support military action as a plausible response to the terrorist threat (Ruigrok, 2007: 16).

Media's major role in the constitution of the Arab-as-terrorist enemy, alongside right-wing Orientalist rhetoric in that sense, helped create a climate of constant fear reflected in the sweeping public support of government action against the terrorist danger. For instance, a Gallup survey conducted immediately after the $9 / 11$ attacks indicated that $49 \%$ of respondents admitted that terrorism was the "most important problem facing the nation" (Schmidt, 2014: 161).

Overall, a great deal of studies conducted on the framing of Arabs and Muslims confirmed an unprecedented upsurge in the number of published or broadcast material backing the war on terror and to gather consensus around the government's agenda in this respect. Hence, departing from the neo-Orientalist postulate viewing Islam as a breeding ground for violence and terrorism, and Muslims as unfit to live in a democracy, media discourse in the aftermath of 9/11 crystallized into a massive support for government's policy. Following Bush's declaration of the War on Terror in 2001, the vast majority of news media adopted a tougher editing line that further fostered the binary language, and deeply impacted the public discourse. To this end, in the terms of Ruigrok, "stories were framed, angled, geared and worded to suit the emotional and cognitive framework of audiences at home" (Ruigrok, 2007).

To take just a few examples, the number of articles published in The New York Times and referring to Arabs and Muslims skyrocketed by more than 1000\% just between September 2001 and March 2002 (Schmidt, 2014: 139). Another poll conducted by the same institution (Gallup) revealed that $33 \%$ of the surveyed sample went so far as to question the national loyalty of their Arab American fellow citizens, utterly placing them on the side of the terrorist enemy (Schmidt, 2014: 139). Later surveys confirmed the same trend. For instance, a poll conducted by USA Today in July 2006, uncovered that 34\% of Americans believed that American Muslims tended to sympathize with Al Qaeda (Wöhlert, 2007: 2).

In summary, while it seems difficult to establish a formal link between Orientalist scholars and opinion leaders in the media in their much-publicized campaign to denigrate Arabs and Muslims, it is pertinent to recognize an unspoken resolve animating both realms to systematically associate terrorism with Islam, and ultimately justify political decisions in that respect.

Additionally, empirical data on Arab/Muslim misrepresentation in academia and media unveiled a shared determination to foster a political agenda and secure public support for its implementation both at the domestic and foreign levels. This amounts to tightening the grip around the Arab and Muslim communities, including trespassing on their constitutional rights in the name of national security, and justifying military presence in the Middle East under the pretext of containing Islamic fundamentalism and spreading democracy. As clearly demonstrated by Michael Ryan who, in a content analysis of 104 editorials published in ten major newspapers, found that 75 contained strongly one-sided stories written for the purpose of gaining public backing for the war of the 'West' against the 'barbaric East' (Schmidt, 2014: 150). Similar findings were underlined by Mugheesuddin who, after following three famous newspapers, The New York Times, The Washington Post, and Los Angeles Times, concluded that "most media follow and support the administration's approach in foreign policy issues related to Muslims and Islam" (qtd. in Reza, 2014: 238).

\section{Challenging the Orientalist Discourse}

Situating the debate in a wider context to explore the roots of the 'Orient' vs. 'Occident' dichotomy entails investigating the Orientalist rhetoric from different perspectives, and testing its binary frame patterns on the ground of reality. This implies dismantling anti-Arab/Muslim stereotypes constructed in U.S. media and academia to principally fit and advance a political agenda. Arguably, only a few content analysis studies have been carried out, to date, to unearth Orientalist inconsistencies, namely how an impressive proportion among American opinion leaders utterly failed to offer an accurate and truth-like picture of Arab and Muslim categories.

A major incongruity highlighted by critics of Orientalist thought called attention to the uniform and homogenizing image of Arabs/Muslims disseminated by both news actors and Orientalist polemicists racializing them as a monolith. In so doing, they not only failed to grasp the difference between being 'Arab' and being 'Muslim' as often they used them interchangeably, but also continued to conflate Arabs in the diaspora and their counterparts in the Middle East with whom they certainly shared a common cultural heritage, but by no means the same mind frames, lifestyles, or social behavior. In addition to official counts documenting Arabs as a minority group representing roughly $23 \%$ of the Muslim population worldwide (Pew research Center, 2017), the majority of Arabs based in the United States (2/3) are Christian and self-identify more as 'Americans' than 'Arabs' (Zogby, 1990). Thus, contrary to the belief that Arabs and 
Muslims originate from the same legacy, speak the same language, and share the same values and lifestyles, the first (Arabs) are religiously diverse as they also include Christians and Jews, and the second (Muslims) are racially dissimilar, comprising Asians, Africans, Amazigh, etc. What's more, featuring Islam as the breeding ground of terrorism, and scapegoating the 1.6 billion Muslims as 'born-to-kill' machines with a natural propensity for violence, implies overlooking the peaceful side of Islamic teachings, and refusing to consider moderate and condemnatory voices among the overwhelming majority of Muslims across the globe.

To Said who attributed the overarching narrative associated with Islam to a patent lack of knowledge of the Arab and Muslim world, Western 'Othering' processes stemmed from a stereotyped image fabricated over time by what he called 'self-designated' scholars who lamentably relied on observation as the only means for collecting information. On this account and because their approach was historically based on very often unsubstantiated and out-of-context approximations, their depictions of Islam and Muslims were simply devoid of any scientific or rational credit (Said, 2000). As confirmed by Afnan Qutub who maintained: "Western scholars have based their assumptions on academic knowledge without even having visited a Middle Eastern culture. Hence, their conclusions often tend to be partial, misleading, and deceptive" (Qutub, 2013: 242).

Consistent with this trend, the shift after 9/11 from traditional Orientalism (basically cultural and ideological) to neo-Orientalism (more political and sustained by the war on terror) (Schmidt, 2014) foreshadowed the advent of a new discourse that catapulted the "Muslim terrorist" stereotype to the forefront of popular consciousness, providing as a consequence fertile ground for discrimination and 'Othering.' To Said, besides an obvious goal to vilify Muslims, Orientalist polemicists (like Daniel Pipes, Robert B. Spencer, and Stephen S. Shwartz) sought to "excoriate Islam for its terror, despotism and violence, while assuring themselves profitable consultancies, frequent television appearances and book contracts" (Said, 1981: 16).

Challenging the Orientalist thought also meant deconstructing media binary frames, especially bias as a widespread characteristic of news coverage and news reporting about Arabs and Muslims. This signifies a closer examination of media contents in this regard, principally the mechanisms deployed to feature Arabs and Muslims as the 'enemy-Other.' More importantly, with the emergence after $9 / 11$ of media as key political actor in a sweeping campaign to villainize such communities within and outside U.S. borders, it seems coherent to unveil unethical practices utilized mainly by news agents who, with the intent to amplify the terrorist menace, spread misinformation based on pre-conceived stereotypes devoid of any justification.

In his book Covering Islam (1981), Said questioned the objectivity of Western journalistic reporting long before the events of 9/11, arguing that by incessantly blurring the lines between reporting and propaganda, news actors failed altogether to cultivate equity and justice. In addition, in his view, to Orientalist discourse being articulated around three main features (race, religion, and gender), the widely conveyed negative picture of Arabs/Muslims in Western media was politically-motivated and tailor-sized to enhance and promote a political agenda. To him, the Western media's success "of this coverage can be attributed to the political influence of those people producing it rather than necessarily to truth and accuracy" (Said,1981:166). Viewed from this perspective, media misrepresentation of such categories not only propagated fear of the Arab/Muslim 'Other,' but further imprinted the American mindset, reinforcing thereby the historically-ingrained 'us' vs. 'them' paradigm.

Symptomatic of a highly-mediatized campaign unfairly targeting Arabs and Muslims, the constant equation of such groups with epithets such as 'terrorist,' 'vengeful,' 'unreasoning,' aimed according to Said to tarnish their image in the public arena as much as to gather support for Bush's domestic and foreign policy measures in his war on terror. On practical grounds, this implied backing and justifying a battery of oppressive decisions taken in the name of national security to impose severe restrictions on local Arab and Muslim communities, or the 'enemy within,' while spreading distorted information to legitimize military intervention in the Middle East as part of a national strategy to decimate terrorist networks and diffuse democracy (Said, 1978).

Media-fabricated stereotypes of Arabs and Muslims did not only parallel the political establishment 'canon,' even if that meant endorsing what some referred to as "state-sponsored racism," they also served the lucrative goals of profit-making corporate media conglomerates. This translated into conceptualizing sensational and fantasized images of the aforementioned categories for the sake of widening the scope of their audiences, and deriving consequential financial return. As underlined by Said: "it ought to go without saying that the media are profit-seeking corporations and therefore, quite understandably, have an interest in promoting some images of reality rather than others" (Said, 1981: 49).

Interestingly, presenting facts in a biased and prejudicial way has often been part of a manipulative strategy adopted by a large number of American written and broadcast media to impact the public discourse and fashion the way their audiences approach the news associated with Arabs and Muslims. Thus, by homogenizing these diverse categories as a 
monolithic bloc in terms of a pseudo collective engagement to promote political Islam, they fell in the trap of 'racialization' as their peers among Orientalist scholars. Thereby, by systematically associating terrorism with these groups, even if sometimes the perpetrators were non-Muslims, their goal was simply to magnify public fear and further stigmatize them. As highlighted by McQueeney: "terrorism is constructed through the interpretation of events, the use of claims made up of language and symbols, and the work of claim-makers to attract the public's attention and sway public support of some interests over others" (McQueeney, 2014: 298).

To illustrate with just one example, when in 1995 Timothy McVeigh, a former U.S. army soldier and security guard, bombed a federal government building in Oklahoma City, killing 168 people and injuring over 680 others, major news outlets rushed to judgment pointing the fingers at 'Middle Easterners' as, based on their logic, terrorist attacks could not be perpetrated by people other than Arabs and Muslims (McQueeney, 2014: 304). In other words, Arabs/Muslims were always "guilty until proven innocent" (Nurullah, 2010: 1033). Paradoxically, when it was the case, as engendered by the above-cited example or other domestic events of mass killing, media reports strategically avoided the use of the term 'terrorist,' referring to the perpetrators as 'lunatics,' 'lone wolves,' or simply 'psychotic types with little political background' (Perspectives on Terrorism, 2010). For instance, covering the Oklahoma events, CBS newswoman Connie Cling declared: "US government sources told CBS News that it (the bombing) had Middle East terrorism written all over it" (qtd. in Nurullah, 2010: 1032).

Particularly noteworthy was, according to Conte, the utter failure of Western media in pinpointing the discrepancies between the teachings of Islam and what an infinitesimal minority of radical fanatics made of it. As a remedy, he suggested to drop the word 'Muslim,' most often used in conjunction with other terms such as 'fundamentalists,' 'extremists,' 'terrorists,' or 'fanatics.' Conte believed that such associations practically never applied to non-Muslim activists involved in terrorist attacks, and whose religious profile almost never appeared in media reports. As a matter of fact, militants of the Irish Republican Army were not referred to as Catholic terrorists. The same applied to members of the Ulster Freedom Fighters who were never called Protestant terrorists (Conte, 2001).

In the same vein, Mahathir Mohamad noticed that most Western media followed an imbalanced editorial line in dealing with security issues. He especially underscored how a large number of European and American news outlets almost never associated terrorism with other faiths, namely Christianity, Judaism, or even Buddhism and Hinduism, albeit disparate attacks committed in their name. He argued: "Hindu attacked Muslims in the name of Hinduism (in Gujarat and elsewhere in India) but they are not called Hindu terrorists. The Catholics and Protestants in Northern Ireland terrorized each other but are not called Christian terrorists. But if misguided Muslims attack non-Muslims they are labeled Muslim terrorists" (Mohamad, 2002: 2).

One last instance that clearly mirrors Orientalist bias in U.S. media, chiefly the lack of critical analysis and independent thinking on the part on certain news agents, concerned the coverage of the Palestine question and its centrality to the rhetoric around 9/11. Once again, despite bin Laden's declaration in his second video recording (Nov. 3, 2001), speaking about 'revenge for Palestine' as the main drive behind the attacks, the coverage of the Middle East conflict in relation to 9/11 was downplayed by almost all American news organs, attributing the events rather to notions pertaining to the clash of civilizations paradigm. As stressed by Dennis Ross, former envoy to Middle East: "bin Laden's hatred had no relationship to Palestine, but it was really his hatred for modernity and the West" (qtd. in Reza: 238). Yet, the assaults in question, according to Fred Halliday of The Guardian, definitely "emerged from political tensions in Palestine, not nonsense talk of clash of civilizations" (qtd. in Reza: 239).

\section{Conclusions and Projections}

In light of the above literature, a wide range of conclusions can be drawn, as the complexity of the issue cannot be reduced to a mere 'us' vs. 'them' dichotomy. Nor can it be confined to a constraining display of arguments and counter-arguments underpinning the debate over Orientalism. Questioning certain aspects of the Orientalist discourse, namely its conformity with ground reality, is one of them. Actually, in addition to anti-Orientalist rhetoric that explored the root tenets of such an ideology in an attempt to capture the essence of its claims and deconstruct its foundational paradigms, a number of empirical studies revealed striking shortcomings as to the approaches utilized by Orientalist scholars and media agents to gather, process, and diffuse data related to Arabs and Muslims. This is manifested in an outright failure to produce scientifically credible knowledge, as much of the propagated information with regard to those categories was either based on unfounded assumptions or triggered by biased value-judgements. To Said who trusted the "hermeneutically trained minds" to think critically and reject pre-conceived stereotypes, there is manifestly not much empirical data to lend credence to Orientalist assertions (Schmidt, 2014).

What's more, deconstructing Orientalist discourse also meant debunking the clash of civilization paradigm recurrently used by Orientalist academics, and unfittingly showcased by mainstream media to reinforce the 'Othering' process. As a result, not only both realms of influence often provided discursive definitions of certain terms such as 'fundamentalism,' 
'fanaticism,' 'terrorism,' etc., but also used them out of context to flaunt the specter of violence and augment public fear (Reza, 2014). To Norris and Inglehart, the use by Orientalists of the clash of civilizations construct as a means to further widen the gap between 'Occident' and 'Orient' was simply improper and counterproductive in a context of fruitful academic and scientific exchange between the different cultures and civilizations. In their view, because it operated through "de-contextualization and de-historization," the construct simply brought about a "clash of scholarship" (Schmidt, 2014: 144). In the same vein, critics of the Orientalist rhetoric unmitigatedly dismissed the doctrine in question on the ground that the real clash was not between the Western culture and the Islamic faith, but rather between radicals and moderates on both sides of the spectrum (Abdulla, 2007: 1067).

Embracing a new line of thought and editing that prioritized objective analysis and unbiased coverage also implied abstaining from viewing the 'Other' through the lens of similarity or communality. In this regard, opinion leaders in the media and academia were called to refrain from homogenizing Arab and Muslim communities, and recognize their national, cultural, and religious diversities. By constantly conflating their ethnic origin with their religious affiliation, and spreading the same Orientalist cliché of Arabs/Muslims as eternal evil-doers, they not only locked themselves in same binary trajectory and thought patterns, but also triggered unrelenting cycles of hatred and discrimination targeting especially those in the diaspora. As pointed out by McQueeney: "Media images are not mere rhetoric; they can set the stage for Islamic violence and war" (McQueeney, 2014: 304).

Further insights into the dynamics ruling the Orientalist discourse also revealed an asserted proneness to overlook Arab/Muslim historical achievements, let alone their individual success stories. Correspondingly, their past and recent contributions to human welfare and development were almost never highlighted. "Muslims, after all, adapted Greek philosophy for later European use, were pioneers in logic and astronomy, established medicine as a science and invented algebra," contended Khaldi (qtd. in Reza, 2011: 240).

Finally, while attributing the widening rift between 'Orient' and 'Occident' to ill-intentioned minds among Western Orientalists or a handful of radical Islamists who have hijacked Islam in the name of Jihad against the West remains beyond the scope of this paper, it is imperative nevertheless to suggest possible venues for peaceful exchange between the different cultures and religions. Envisaging solutions grounded in social justice could be one of them. For instance, to deconstruct 'Otherness' and reframe the collective image of Arabs and Muslims, Dabashi proposed embracing new approaches to produce and spread an alternative knowledge to the one publicized by Orientalists and neo-Orienralists. In his view, the solution could be a new form of "post-Orientalism (an alternative Orientalism) that stresses the role of the intellectual not merely as critic but a 'social category" (Dabashi, 2009: 407). To this end, he recommended to "do-Orientalize theory and method," and address the issue from rather a novel perspective that highlighted the universal character of the propagated message (Dabashi, 2009: 407).

Overcoming the Orientalist legacy and raising public awareness of the harmful consequences of binary thought constructs could also stem from a thorough questioning of the mechanisms deployed to fashion and refashion public discourse, including starting from scratch and addressing a 'new interlocutor' likely to internalize new norms for peaceful exchange and cohabitation. This translates into fostering a critical media literacy in which teachers and educators in general are expected to play a leading role, especially protect their audiences from the calamitous consequences of sustained exposure to media contents, and inculcate them with higher values of social justice. As pertinently asserted by McQweeney: "Critical media literacy is an excellent starting point for helping today's young people deconstruct dominant paradigms, practice participatory democracy, and mobilize technology in pursuit of social justice" (McQueeney, 2014: 306).

Ultimately, while it is difficult to gauge how long anti-Arab/Muslim stereotypes will continue to pervade media contents and scholarly discourse in the United States, it is legitimate to highlight the role of alternative media (as represented by Al Jazeera and other independent networks) could play to counter prevailing rhetoric and deconstruct 'Otherness.' But to trigger public discourse in such a heavily-mediated context and supply another voice to the misrepresented, they, alongside Arab/Muslim scholars, are called to offer new lenses through which targeted audiences could perceive another reality.

\section{References}

Abdulla, R. A. (2007). Islam, Jihad, and terrorism in post-9/11 Arabic discussion boards. Journal of Computer-mediated Communication. https://doi.org/10.1111/j.1083-6101.2007.00363.x

Arti, S. (2007). The evolution of Hollywood's representation of Arabs before 9/11: The relationship between political events and the notion of 'Otherness.' Journal of the MeCCSA Postgraduate Network, 1(2).

Bush, G. W. (2001). Statement by the President in his address to the nation. Delivered on September 11, Washington, D.C. http://www.americanrhetoric.com/speeches/gwbush911addresstothenation.htm. 
Cainker, L. (2004). The impact of September 11 attacks on Arab and Muslim communities in the United States. In J. Tirman (Ed,), The maze of fear: Security and migration after, 9/11. New York: The New Press.

Conte, W. (2001, September 28). British media portrayals of Muslims in the wake of the September 11 attacks. http://mit.edu/cms/reconstructions/communications/ukmuslims.html

Dabashi, H. (2009). Post-Orientalism: Knowledge and power in time of terror. New Jersey: New Brunswick Transaction Publishers.

Ernest, C. (2003). Muhammad: Rethinking Islam in the contemporary world. The University of North Carolina Press.

Fries, J. G. (2005). The Evaluation of Hollywood Portrayals of Soviet and Middle Easterners 1980-2000. Ohio: College of Art and Science of Ohio University.

Gullup. (2013). Terrorism in the United States. http://www.gullup.com/poll/4909/terrorism-united-states.aspx

Hatem, M. F. (1998). The invisible American half: Arab American Hybridity and feminist discourses in the 1990s. In E. Shohat (Ed.), Talking visions: Multicultural feminism in a transnational age. Cambridge: MIT Press.

Huntington, S. (1996). The clash of civilizations and the remaking of world order. New York: Simon \& Schuster.

Khatib, L. (2006). Filming the Modern Middle East: Politics in the Cinemas of Hollywood and the Arab World. London: I.B. Taurus.

Lewis, B. (September, 1990). The roots of Muslim rage. The Atlantic. http://www.theatlantic.com

McAlister, M. (2005). Epic Encounters: Culture, media and U.S. interests in the Middle East since 1945. University of California Press.

McQueeney, K. (2014). Disrupting Islamophobia: Teaching the social construction of terrorism in the mass media. International Journal of Teaching and Learning in Higher Education, 26 (2). http://www.iselt.org/ijitlhe

Merskini, D. (2004). The construction of Arabs as enemies: Post-September 11 discourse of George W. Bush. Mass Communication and Society, 7(2). https://doi.org/10.1207/s15327825mcs0702_2

Mohamad, M. (2002). Enhancing the understanding of Islam for the media. In A. A. Razak \& A. B. Abdul Majeed (Eds.), Enhancing the understanding of Islam for the media. Kuala Lumpur: IKIM.

Norris, P., Kern, M., \& Just, M. (Eds.) (2003). Framing Terrorism. In P. Norris. M. Kern, \& M. Just (Eds.), Framing Terrorism: The news media, the government and the public. New York: Routledge.

Pew Research Center. (2017, January 31). World's Muslim population more widespread than you might think. http:/www.pewresearch.org

Pipes, D. (2003). Militant Islam reaches America. New York: W. W. Norton \& Company.

Poole, E., \& Richardson, J. (2006). Introduction. In E. Poole \& J. Richardson (Eds.), Muslims and the news media. London: I.B. Taurus.

Poole, E. (2002). Reporting Islam: Media representations of British Muslims. London: I.B. Taurus.

Qutub, A. (2013, Fall). Harem girls and terrorist men: Media misrepresentations of Middle Eastern cultures. Colloquy, 9, 139-155. http://www.calstatela.edu

Reza, S. M. (2011). Representations of Islam and Muslims in press coverage. World Journal of Islamic History and Civilization, 1(4).

Ridouani, D. (2001). The representation of Arabs and Muslims in Western media. Revista Universitaria de Triballs Academics (RUTA). http://www.raco.cat

Ruigrok, N. (2007, January 1). Global angling with a local angle: How U.S., British, and Dutch newspapers frame global and local terrorist attacks. The International Journal of Press/Politics. https://doi.org/10.1177/1081180X06297436

Said, E. (1978). Orientalism. New York: Vintage Books.

Said, E. (1981). Covering Islam: How the media and the experts determine how we see the rest of the world. New York: Vintage Books.

Sandikcioglu, E. (2010, September 12). Orientalism: The ideology behind the metaphorical Gulf War. Duisberg (GR): Gerhard Mercator University.

Schmidt, S. (2014). (Re-)framing the Arab/Muslim: Mediating Orientalism in contemporary Arab American life writing. Transcript Verlag. https://doi.org/10.14361/transcript.9783839429150 
Semaan, G. (2014). Arab Americans: Stereotypes, conflicts, history, cultural identity and Post 9/11. International Communication Studies XXIII: 2. http//web.uri.edu

Shaheen, J. G. (1984). The TV Arab. Ohio: Bowling Green State University Popular Press.

Shaheen, J. G. (1997). Arab and Muslim stereotyping in American popular culture. Washington, D.C.: Georgetown University Press. Center for Muslim-Christian Understanding.

Shaheen, J. G. (2000). Hollywood's Muslim Arabs. Muslim World, 90 (1-2). https://doi.org/10.1111/j.1478-1913.2000.tb03680.x

Shaheen, J. G. (2001). Reel bad Arabs: How Hollywood vilifies a people. New York: Olive Branch Press.

Shaheen, J. G. (2012). Guilty: Hollywood's verdict on Arabs after 9/11. Northampton, MA: Olive Branch Press.

Suleiman, M. (1999). Introduction. In M. Suleiman (Ed.), Arabs in America: Building for a new future (1-21). Philadelphia: Temple University Press.

Terrorism Research Initiative (2010, May). Perspectives on Terrorism, 4(2). https://www.jstor.org/stable/e26298442

Wöhlert, R. (2007). Civilization versus barbarism: The images of Arabs and Muslims and the national self-concepts in German and U.S. Media around 9/11. Diss.: Universität Beilefeld.

Zogby, J. (1990). Arab America today: A demographic profile of Arab Americans. Washington, D.C.: Arab American Institute.

Zogby, J. (2010). Arab voices: what they are saying to us, and why it matters. New York: Palgrave Macmillan.

\section{Copyrights}

Copyright for this article is retained by the author(s), with first publication rights granted to the journal.

This is an open-access article distributed under the terms and conditions of the Creative Commons Attribution license which permits unrestricted use, distribution, and reproduction in any medium, provided the original work is properly cited. 